\title{
Competitive Advantages of the Innovative University Ecosystem as the Source of the Competitiveness of Small Innovative Enterprises*
}

\author{
Konstantin Getmantsev \\ Department of Organization and Planning of Local \\ Development \\ Kuban State University \\ Krasnodar, Russia \\ Vladimir Ermolenko \\ Department of General, Strategic Management and Business \\ Processes \\ Kuban State University \\ Krasnodar, Russia
}

\author{
Tatyana Myasnikova \\ Department of State and Municipal Administration \\ Kuban State University \\ Krasnodar, Russia
}

\author{
Daria Lanskaya \\ Department of General, Strategic Management and Business \\ Processes \\ Kuban State University \\ Krasnodar, Russia
}

\begin{abstract}
The present article studies a small innovative enterprise as an effective form of commercialization of scientific results, analyses its life cycle, the issues of its formation, functioning and development, and examines a range of conditions and factors for the successful operation of an innovative university ecosystem and a small innovative enterprise. The mechanisms of enterprise activity service and the projected activities to introduce the innovations to the market are considered the central problems of the article. The hypothesis of the present research is as follows: the infrastructure of the innovative university ecosystem is an economic agent; it is characterized by the methods of working with innovations, which small innovative enterprises introduce to promote on the innovation market. The subject of the research is the mechanisms of enterprise activity service and the intellectual services of the innovative university ecosystem provided to small innovative enterprises to facilitate their successful introduction into the innovation market. The article is aimed at studying the properties of a small innovative enterprise as an operational core; in order for this core to function effectively, the innovation university ecosystem performs a service function and provides intellectual services, such as management, engineering, technological, financial, investment, marketing, accounting services, etc. In the research the authors have formulated the properties of the innovative ecosystem as an environmental system, proposed its model and substantiated the service nature of its activity, as well as have analysed the life cycle and performance criteria of a small innovative enterprise.
\end{abstract}

Keywords-innovation ecosystem infrastructure; small innovative enterprise; intellectual deliverables; innovation market; intellectual services; forms of innovations commercialization

*Project: The study was carried out with financial support from the Russian Foundation for Basic Research in the framework of the scientific project No. 18-010-00220

\section{INTRODUCTION}

Relevance of the research: Small innovative enterprises, their formation, functioning and development continue to generate a growing interest among researchers and innovators worldwide, as they are considered an effective tool for commercializing intellectual deliverables [19]. According to the Russian Science Citation Index, presently about 5,000 published scientific articles are devoted to the range of issues of small innovative enterprises. [20].

Small innovative enterprises are established for the purpose of commercializing the results of research, development and technological works. They are created at the universities of the entrepreneurial type, which are characterized by the following distinguishing features:

- account for international experience of successful innovations and stimulation of entrepreneurial activity of the innovative university ecosystem;

- the focus on the precedence of basic scientific research and flexibility in taking new scientific directions;

- $\quad$ the ability to generate modern knowledge and provide its transfer;

- creating a special environment that ensures scientific knowledge transfer and liberalized relations between the objects of the internal university environment of the flexible network structure

- intellectualization of university management, transforming the nature and concepts of the hierarchical relationship to management services; 
The interest in creating research and innovation infrastructure has resulted in a variety of infrastructure types, which not infrequently duplicate each other.

The methodological basis of the research is represented with the method of systemic and functional analysis, comparative analysis, expert evaluation method and case study.

However, the particular issues of small innovative enterprises do not reflect the large-scale transformation of the innovative university ecosystem competitive advantages into the competitiveness of a small innovative enterprise.

Therefore, the central problem of the innovative university ecosystem is the mechanisms of small innovative enterprise activity service and the projected activities and necessary works to introduce the innovations to the market.

The hypothesis of the research is as follows: the infrastructure of the innovative university ecosystem is an economic agent; it is characterized by the methods of working with innovations, which small innovative enterprises introduce to promote on the innovation market.

The subject of the research is the mechanisms of enterprise activity service and the intellectual services of the innovative university ecosystem provided to small innovative enterprises to facilitate their successful introduction into the innovation market.

The purpose of the article is to study the properties of a small innovative enterprise as an operational core; in order for this core to function effectively, the innovation university ecosystem performs a service function and provides intellectual services, such as management, engineering, technological, financial, investment, marketing, accounting services, etc.

\section{COMPARATIVE ANALYSIS OF THE WAYS OF COMMERCIALIZING INTELLECTUAL DELIVERABLES}

There exist several mechanisms for commercializing innovations and attracting investments [1], [21].

A conventional, though less effective mechanism: performing research and development under the agreement with a customer. The first financing mechanism for applied research is generally based on personal relations of researchers and is unlikely to be long-term and sustainable in the dynamic environment. However, due to information technologies development, tenders can be held on special platforms, which contain proposals from enterprises and organizations for providing research and development services. The scientific result obtained under the contract is either used by the customer or not. This mechanism can be called quasi-market: it does not generate income, which is subsequently capitalized on the innovation market, and the expenditures for creating the result of intellectual activity are not covered by profit; in a best-case scenario, the profit is minimal. This is a non-dynamic result of intellectual activity, which does not always develop into an innovation. Meanwhile, the result of intellectual activity depends on customer needs.

The second mechanism is registering intellectual property items and subsequently selling them on the innovation market. 
- creating problem-oriented methods and software tools to support strategic development of small innovative enterprises;

- evaluating small innovative enterprises potential and performance;

- the transition in from hierarchical structures to complementary network and cluster forms of intercompany interaction within a new development model and to mechanisms for implementing the network model of business incubation, when building economic systems;

- creating and developing the infrastructure of the knowledge economy innovation ecosystem and the transition to its model based on unified standard elements;

\section{ACTIVITIES OF THE INFRASTRUCTURE UNITS OF THE} INNOVATIVE UNIVERSITY ECOSYSTEM

The performance of small innovative enterprises is affected by two groups of factors:

- the first group - the productivity of the issues under development, the topic, its relevance to research priorities, the qualifications and experience of researchers;

- the second group - the quality of the services provided by the infrastructure of intellectual property items registration, engineering support, project documentation development, marketing support, accounting.

The overview of works on creating innovative university ecosystems and small innovative enterprises has shown that the research primarily focus on finding solutions to the following problems, which indicates the "transformation of focal topics":

- a small innovative enterprise as a transition from a scientific idea and the formation of intellectual resources to a product, as drivers for commercializing intellectual deliverables and the more preferable form in the system of the institutions of the regional knowledge economy infrastructure and the implementation of a new industrial policy;

- creating small innovative enterprises, organizational and economic mechanisms, organizational and legal management issues and viable models;

- the economic role, development features, mechanisms for stimulating technological entrepreneurship in Russia and international innovation corridors as its infrastructure factors;

- developing professional services in the innovation and venture capital industry and establishing service companies;

- tools for financing small innovative enterprises at early stages of their activity, their interaction with regional institutions and ensuring their investment attractiveness;
- creating the favourable environment for small business and entrepreneurship development: business incubators, technology parks, etc.;

- the approaches and methods for innovative processes management, the synthesis of strategies for the formation of innovative ecosystem elements and applying the management control system when managing them as an intellectual service [5], [7], [8], [9].

The activity of a small innovative enterprise is formal in nature [2], [4]. The stereotype which is observed in the work of an ordinary small enterprise could not be overcome. Even in theory, when discussing the issues of structuring the internal environment, the problems of engineering, marketing, investment, documenting intellectual deliverables, etc. are expected to be solved there. These are exactly the tasks that infrastructure units are to solve for the benefit of a small innovative enterprise; otherwise, there is no sense in the innovative university ecosystem. Business incubators, innovative technology parks and other units, perform some of the tasks of introducing innovations to the market. Therefore, having to solve the complex of problems on their own, without infrastructure involvement, small innovative enterprises operate but do not produce satisfactory results. A small innovative enterprise as an economic agent and as a product of the innovation process exists as an opportunity for innovative product creation. However, such an approach to organizing the activity of small innovative enterprises and the infrastructure of the innovative university ecosystem does not ensure the innovation having the properties of an innovative product, which in its turn does not enter the innovation market. Not infrequently, infrastructure units exist for their own sake. The positive practice of the innovative ecosystems operation in a number of universities in Russia, Israel, Finland, Germany and other countries indicates that the infrastructure should perform the works and services that ensure the transformation of innovations into innovative products and their introduction to the market [14]. Even though small innovative enterprises established as a form of commercialization are numerous, there are very few examples of their purchase and sale. The profit from innovation in some Russian universities' innovative 
ecosystems is rather modest, while in others there is simply no profit at all.

The national innovation ecosystem is a new concept of interconnected institutions (research and innovation organizations) that provide generating new knowledge, its accumulation and storage, transfer and transformation into new technologies, innovative products and intellectual services in order to meet the requirements of the society, economic and social agents and individuals.

The innovative ecosystem is a multi-level environmental system [12], which consists of regional, corporate, university, and municipal components.

The innovative university ecosystem is a system of innovative institutions providing knowledge transfer that leads to the transformation of innovations and their introduction to the market in the form of innovative products or services of new value.

The formation of the innovative university ecosystem is grounded on H. Mintzberg's ideas on creating a certain environment of unique properties for ensuring the effective transfer of knowledge and its transformation into innovative products [17].

\section{THE LIFE CYCle AND Business Models OF A SMALL INNOVATIVE ENTERPRISE}

According to innovative management, small innovative enterprises are considered as a more productive way of attracting investment in the innovative university ecosystem. The creation and registration of a small innovative enterprise is not a goal in itself, but just a way of allocating property rights to the final product, to innovation, with an investor being attracted at the stage prior to commercialization. This is not an easy opportunity for university innovators to attract investment, but there is no other effective way yet.

Meanwhile, such categories as an opportunity and a reality should be clearly distinguished. Attracting investment through the mechanism of allocating property rights, which is aimed at creating innovation, promoting it on the market and subsequently implementing it, is an opportunity.

The risk universities face is that the allocated property rights are to the products that do not exist yet. The commercial potential of such an innovation (product) in the future may be rather high. However, the risk of profit not covering the costs of creating innovation is also high. In this regard, dynamic cost accounting for innovation creation is becoming more relevant. Thus, the methods of management accounting may be applied, including full cost calculation, calculating costs at life cycle stages, and the process cost calculation method. [6], [16].

Therefore, the number of created small innovative enterprises does not indicate the university's innovative viability. The indicator of attracted credit resources through small innovative enterprises co-founding, the number of small innovative enterprises' founders, their contribution to the nominal capital and net profit from small innovative enterprise sales received by the university are much more illustrative.
Creating a small innovative enterprise with the help of a business incubator of technological park services in just the very beginning of innovation activity, therefore, at the initial stages it is essential to structure the multi-factor process of successful innovation. The success of a small innovative enterprise is ensured not by the effectiveness of functional management, but of the process management of the entire the innovative university ecosystem infrastructure, when all its elements focus on end results. Current developments are expected to grow into innovations; Innovations are developed by science, while current developments - by the innovative university ecosystem, one of the elements of which is a small innovative enterprise. Therefore, the innovative university ecosystem infrastructure should work as an innovation market agent. There should be a motivation system for the innovative university ecosystem staff, an effective contract with modified and balanced systems of performance indicators.

Moreover, multilateral contract are reasonable to conclude to promote innovation on the regional, federal and even international innovation market. The contract parties may include:

- university, as the innovation proprietor, represented by the rector;

- co-founders of the small innovative enterprise;

- $\quad$ researchers and developers;

- heads of infrastructure units of the innovative university ecosystem.

The nucleus of a small innovative enterprise is represented by a creative team of researchers under the leadership of a research supervisor.

The method of registering intellectual property and subsequently selling this intellectual property item on the innovation market is characterised by an intermediate position in terms of effectiveness. This mechanism does not imply direct commercialization in the process of intellectual assets capitalization. What is more, both the author and the university-proprietor lose their rights to use it. Thus, when publishing the information about the intellectual property item, for instance, the author is to receive a written permission from the new owner.

In a number of universities, small innovative enterprises are created with no account of potential or real investors, but in the hope that they will appear. Thus, the situations when de jure, small innovative enterprises exist, but in fact their activities are low-key due to the lack of investors and financing are not rare. There are several reasons for this: underperformance of the innovative university ecosystem infrastructure on the innovation market to promote intellectual deliverables (potential investors were not found), the research topic is not relevant, the insufficient scientific research at the university, etc.

If there is an innovation centre, the procedures for enterprise organization are performed at full speed and all stages of work on commercializing innovations at the 
- optimizing risks and profitability of activities when providing service support and supporting the entrance to the innovation market.

\section{CONCLUSION}

The key competitive advantage of the innovative university ecosystem as an environmental system consists in the service nature of its activity in relation to small innovative enterprises. The infrastructure of the innovative university ecosystem is an economic agent; it is characterized by the methods of working with innovations, which small innovative enterprises introduce to promote on the innovation market. Mega business-process of commercializing innovations within the innovative ecosystem is market-orientated; it involves small innovative enterprises that receive a complex of services, such as management, engineering, technological, financial, investment, marketing, accounting services, etc. market, etc.;

- factors identifying competitive advantages of the innovative university ecosystem: the quality of intellectual services provided at the request of small innovative enterprise and competencies in the field of service support of the innovation development process (engineering, technological, marketing, investment, registration of intellectual property items, etc.).

The main final criterion for the small innovative enterprise success is the profit made by the university from selling a small innovative enterprise on the innovation market, which covers the costs of its establishment, research and indirect infrastructure costs for servicing its activities.

The presence of a venture investor, a potential buyer, providing seed financing can be considered a working criterion.

Profitability of the a year's innovative project portfolio developed by small innovative enterprises and implemented on the innovation market by the infrastructure can be considered a criterion for the successful and efficient functioning of the university innovation ecosystem.

The key factors for small innovative enterprise successful activities within the innovative university ecosystem include:

- the process management of innovations commercialization and project-based research and services performed by infrastructure units for further introduction of innovations to the market;

- the developed infrastructure of the innovative university ecosystem, characterized by a service entrepreneurial nature and providing a complex of marketing, financial, engineering, legal services (supporting entrance to the innovation market);

- price formation in the innovation market: for contractual research, development and technological works, for intellectual property items and for the International Investment Corporation;

- combining the matrix and the project-focused organizational structures of the innovative university ecosystem;

\section{REFERENCES}

[1] Akmaeva R.I. Innovation management of a small enterprise working in the science and technology field: textbook / Rostov-on-Don, 2012.

[2] Anishchenko Yu.A., Ragozina M.A., Safronov M.V. Methodology for assessing the performance of a small innovative enterprise // Fundamental Research. 2015. No. 9-1. Pp. 106-110.

[3] Afonasova M.A. Analysis of the approaches to creating and ensuring sustainable network structures in the innovation sphere // Fundamental Research. 2014. No. 5 (part 5). Pp. 1058-1062. Available at: http: //www.fundamental-research.ru/ru/article/view? Id = 34045 .

[4] Bakhturin G.I., Turko T.I., Khramov N.B., Fedorkov V.F., Boretskaya S.M. The results of the monitoring and the analysis of small innovative enterprises activities// Innovation and Expertise: scientific works. 2015. No. 1 (14). Pp. 153-162.

[5] Blaug M. Clark, John Bates. Great Economists before Keynes: An introduction to the lives \& works of one hundred great economists of

[6] Boyko A.I., Voronina L.A., Ratner S.V. The structure of the management control system of small innovative enterprises / Innovation Management - 2010. Proceedings of the international research and practical conference. November 15-17, 2010. Pp. 221-225.

[7] Vodichev E. Research universities in the USA: analysis of the features and development priorities in the context of Russian university system reformation. Availanle at: webcache.googleusercontent.com.

[8] Grasmik K.I., Khamazina A.M. Small innovative enterprises at universities: what affects their creation and growth // Bulletin of the Far Eastern Federal University. Economics and Management. 2016. No. 3 (79). Pp. 76-85.

[9] Evseeva O. A. Project approach as a way to develop the commercialization process in high school / O. A. Evseeva, S. A. Evseeva // Bulletin of the Tyumen State University. Socio-economic

[10] Ermolenko V.V. Problems of formation and development of the infrastructure of the innovation ecosystem of the knowledge ecomony as a part of agrarian and industrial complez of the region / V.V. Ermolenko, M.M. Gerashchenko, S.G. Babeshko, D.V. Lanskaya // Political electronic scientific journal of the Kuban State Agrarian University (Scientific journal of KubSAU) - Krasnodar: KubSAU, 2016 No. 09 (123). Pp. 583 - 604.

[11] Zotova E.N., Ishmukhametov N.S. The functioning of small innovative enterprises in the context of knowledge economy development // In the world of scientific discoveries. 2015. No. 5-4 (65). Pp. 1274-1288.

[12] Kleiner G.B. The new theory of economic systems and its application // Bulletin of the Russian Academy of Science. 2011. September. Pp. 1-25. the past. - St. Petersburg: Economicus, 2008. 352 p. and legal studies. 2016. V. 2. No. 3. Pp. 214-225. 
[13] Kondratova N.V., Sumina O.E. Small innovative enterprises: a key source // Socio-economic phenomena and processes. 2014.V. 9. No. 8. Pp. 125-131.

[14] Kuznetsova E.Yu., Ioda Yu.V. Small innovative enterprises at universities: foreign experience and the practice of functioning // Socioeconomic phenomena and processes. 2015.Vol. 10. No. 12. Pp. 35-38.

[15] Lazko M.V., Semchuk N.M. The formation of intellectual resources: from an idea to a product through a small innovative enterprise // Human Resources and Intellectual Resources Management in Russia. 2014.V. 3. No. 4. Pp. 30-33

[16] Lanskaya D.V. Controlling in the innovation ecosystem of the university of the agro-industrial region / V.V. Ermolenko, M.M. Gerashchenko, I.A. Polyakova, D.V. Lanskaya // Political electronic scientific journal of the Kuban State Agrarian University (Scientific journal of KubSAU) Krasnodar: KubSAU, 2016. - No. 09 (123). Pp. $558-582$.

[17] Mintzberg H. Structure in the fist: the creation of an effective organization / Transl. from English Ed. Yu.N. Kapturevsky. - St. Petersburg. 2002. $512 \mathrm{p}$.

[18] On introducing amendments to certain legislative acts of the Russian Federation on the creation of budget scientific and educational institutions of business entities for the practical application (implementation) of the results of intellectual activity. Federal Law of the Russian Federation 217 - FZ dated August 2, 2009.Development of innovative ecosystems at universities and research centres. SPb. 2015. Available at: http://www.maginnov.ru/assets/ files / analytics / razvitieinnovacionnyh-ekosistem-vuzov-i-nauchnyh-centrov.pdf

Russian Science Citation Index. Available at: // elibrary.ru. 